Research Paper

\title{
Properties of catechol 1,2-dioxygenase in the cell free extract and immobilized extract of Mycobacterium fortuitum
}

\author{
A.S. Silva ${ }^{1}$, R.J.S. Jacques ${ }^{2}$, R. Andreazza ${ }^{1}$, F.M. Bento ${ }^{3}$, \\ L.F.W. Roesch ${ }^{4}$, F.A.O. Camargo ${ }^{1}$ \\ ${ }^{1}$ Departamento de Solos, Universidade Federal do Rio Grande do Sul, Porto Alegre, RS, Brazil. \\ ${ }^{2}$ Departamento de Solos, Universidade Federal de Santa Maria, Santa Maria, RS, Brazil. \\ ${ }^{3}$ Departamento de Microbiologia, Universidade Federal do Rio Grande do Sul, Porto Alegre, RS, Brazil. \\ ${ }^{4}$ Universidade Federal do Pampa, Campus São Gabriel, São Gabriel, RS, Brazil.
}

Submitted: April 29, 2011; Approved: July 2, 2012.

\begin{abstract}
Polycyclic aromatic hydrocarbons $(\mathrm{PAH})$ are carcinogenic compounds which contaminate water and soil, and the enzymes can be used for bioremediation of these environments. This study aimed to evaluate some environmental conditions that affect the production and activity of the catechol 1,2-dioxygenase (C12O) by Mycobacterium fortuitum in the cell free and immobilized extract in sodium alginate. The bacterium was grown in mineral medium and LB broth containing $250 \mathrm{mg} \mathrm{L}^{-1}$ of anthracene $(\mathrm{PAH})$. The optimum conditions of $\mathrm{pH}(4.0-9.0)$, temperature $\left(5-70{ }^{\circ} \mathrm{C}\right)$, reaction time (10-90 $\mathrm{min}$ ) and the effect of ions in the enzyme activity were determined. The Mycobacterium cultivated in LB shown higher growth and the $\mathrm{C} 12 \mathrm{O}$ activity was two-fold higher to that in the mineral medium. To both extracts the highest enzyme activity was at $\mathrm{pH} 8.0$, however, the immobilized extract promoted the increase in the $\mathrm{C} 12 \mathrm{O}$ activity in a $\mathrm{pH}$ range between 4.0 and 8.5 . The immobilized extract increased the enzymatic activity time and showed the highest $\mathrm{C} 12 \mathrm{O}$ activity at $45^{\circ} \mathrm{C}, 20^{\circ} \mathrm{C}$ higher than the greatest temperature in the cell free extract. The enzyme activity in both extracts was stimulated by $\mathrm{Fe}^{3+}, \mathrm{Hg}^{2+}$ and $\mathrm{Mn}^{2+}$ and inhibited by $\mathrm{NH}^{4+}$ and $\mathrm{Cu}^{2+}$, but the immobilization protected the enzyme against the deleterious effects of $\mathrm{K}^{+}$and $\mathrm{Mg}^{2+}$ in tested concentrations. The catechol 1,2-dioxygenase of Mycobacterium fortuitum in the immobilized extract has greater stability to the variations of $\mathrm{pH}$, temperature and reaction time, and show higher activity in presence of ions, comparing to the cell free extract.
\end{abstract}

Key words: anthracene, enzyme activity, enzyme immobilization, biodegradation, waste treatment.

\section{Introduction}

In the current years, a high number of polluting compounds have been released into the environment by several anthropogenic activities. In particular, aromatic pollutants have caused the contamination of soil and water with negative impacts on environmental quality and healthy. Furthermore, it is already known that many aromatic compounds show high toxicity and cancerous proprieties for human and animals (Constantini et al., 2009).

Over the last decades, it is increasing the interest in biological methodologies, collectively indicated as biore- mediation that may help to reduce the risk of organic pollutants and effectively remediate polluted sites (Andreoni and Gianfreda, 2007). Liquid effluents contaminated with aromatic compounds can be efficiently processed with microbial enzymes, which compared to microorganisms have the advantage to not be affected by inhibitors of microbial growth; they act in various environmental conditions and are not susceptible to microbial competition (Mateo et al., 2007).

The enzymes catechol dioxygenases add two oxygen atoms to the aromatic ring, disrupting chemical bonds and allowing opening this ring (Whiteley and Lee, 2006). The

Send correspondence to R. Andreazza. Universidade Federal do Rio Grande do Sul, Av. Bento Gonçalves 7712, 91541-000, Porto Alegre, RS, Brazil. E-mail: robsonandreazza@yahoo.com.br. 
catechol 1,2-dioxygenase (C12O) (EC 1.13.11.1) contains $\mathrm{Fe}^{+3}$ as prosthetic group and belongs to the enzymes that make cleavage of catechol as intradiol (or ortho cleavage), producing cis-cis muconic acid (Tsai and $\mathrm{Li}, 2007$ ). The use of catechol dioxygenases for bioremediation has been relatively little explored, although, there is a great potential to use these enzymes mainly associated with the use to bioreactors, to clean high amounts of wastewater contaminated with phenol, benzoate, fluorocatecol, bromocatecol, cholorocathecol, methilcathecol, herbicides (diuron), polychlorinated biphenyls, chloroethanes and others (Duran and Esposito, 2000; Macleod and Daugulis, 2005; Shunkova et al., 2009). For using the catechol dioxygenase on a commercial scale, it is necessary to have large production in laboratory, and to do that, it is necessary to know the environmental conditions that can interfere in its activity.

Despite the many advantages using enzymes in the bioremediation of wastewater, it has been observed that free enzymes tend to show low stability under certain environmental conditions; so, the immobilization technology has been widely used, improving the activity, stability, specificity, selectivity and decreased inhibition (Fernandez-Lafuente et al., 2000; Iyer and Ananthanarayar, 2008). Some studies have shown many supports that can be successfully used to enzymes immobilization (Mateo et al., 2007), but using in large-scale, none of them have many qualities such as calcium alginate, which it is an easy, fast, nontoxic, inexpensive, robust, versatile and widely used to enzymes immobilization (Kalogeris et al., 2006).

The majority of $\mathrm{C} 12 \mathrm{O}$ enzymes were studied with gram negative bacteria and a small number of studies were with gram positive bacteria, in particular with actinobacteria (Shumkova et al., 2009). The latest studies, it was isolated and characterized a powerful microbial consortium that can degrade aliphatic, mono- and poliaromatic hydrocarbons in culture medium and soil (Jacques et al., 2007, 2008). The Mycobacterium fortuitum, a member of this consortium showed high degradation rates and high metabolic versatility. Although, in this study, it was evaluated some environmental conditions that affect the production and activity of the catechol 1,2-dioxygenase from Mycobacterium fortuitum, in the cell free extract and immobilized extract, to further bioremediation use in wastewater treatment.

\section{Materials and Methods}

\section{Microorganism}

An aromatic hydrocarbon degrading microbial consortium was obtained from the enrichment culture of a petrochemical landfarm site (Jacques et al., 2007). This consortium is composed by five bacteria (Mycobacterium fortuitum, Bacillus cereus, Microbacterium sp., Gordonia polyisoprenivorans, Microbacteriaceae bacterium, Naph- thalene-utilizing bacterium) and a fungus, identified as Fusarium oxysporum. To this study, it was used the isolate Mycobacterium fortuitum, a gram-positive bacilli that has capacity to growth using one of the following compounds as unique carbon and energy source when incubated in mineral medium: anthracene, pyrene, phenanthrene, naphthalene, catechol, gentisic acid, toluene, 1-decene, 1-octene, ethanol and gasoline (Jacques et al., 2007). The isolate was stored at $4{ }^{\circ} \mathrm{C}$ on nutritive agar medium $(3 \mathrm{~g}$ of meat extract, $5 \mathrm{~g}$ of peptone, $15 \mathrm{~g}$ of agar in $1 \mathrm{~L}$ of distilled water, $\mathrm{pH}$ 7.0) with $250 \mathrm{mg} \mathrm{L}^{-1}$ of anthracene, a polycyclic aromatic hydrocarbon (PAH) (Kiyohara et al., 1982).

\section{Media and growth conditions}

The isolate was inoculated in Erlenmeyer flasks with Tanner mineral medium (TMM) or Luria Bertani broth (LB), both containing $250 \mathrm{mg} \mathrm{L}^{-1}$ of anthracene as fine crystals (Merck ${ }^{\mathrm{TM}}$, Darmstadt, Germany). The TMM medium was composed by $0.04 \mathrm{~g} \mathrm{~L}^{-1} \mathrm{CaCl}_{2} 2 \mathrm{H}_{2} \mathrm{O} ; 0.1 \mathrm{~g} \mathrm{~L}^{-1}$ $\mathrm{KH}_{2} \mathrm{PO}_{4} ; 0.8 \mathrm{~g} \mathrm{~L}^{-1} \mathrm{NaCl} ; 1.0 \mathrm{~g} \mathrm{~L}^{-1} \mathrm{NH}_{4} \mathrm{Cl} ; 0.2 \mathrm{~g} \mathrm{~L}^{-1} \mathrm{MgSO}_{4}$ $7 \mathrm{H}_{2} \mathrm{O} ; 0.1 \mathrm{~g} \mathrm{~L}^{-1} \mathrm{KCl}$. The micronutrients were prepared as follows: $0.1 \mathrm{mg} \mathrm{L}^{-1} \mathrm{CoCl}_{2} 6 \mathrm{H}_{2} \mathrm{O} ; 0.425 \mathrm{mg} \mathrm{L}^{-1} \mathrm{MnCl}_{2}$ $4 \mathrm{H}_{2} \mathrm{O} ; 0.05 \mathrm{mg} \mathrm{L}^{-1} \mathrm{ZnCl}_{2} ; 0.015 \mathrm{mg} \mathrm{L}^{-1} \mathrm{CuSO}_{4} 5 \mathrm{H}_{2} \mathrm{O}$; $0.01 \mathrm{mg} \mathrm{L}^{-1} \mathrm{NiCl}_{2} 6 \mathrm{H}_{2} \mathrm{O} ; 0.01 \mathrm{mg} \mathrm{L}^{-1} \mathrm{Na}_{2} \mathrm{MoO}_{4} 2 \mathrm{H}_{2} \mathrm{O}$; $0.01 \mathrm{mg} \mathrm{L}^{-1} \mathrm{Na}_{2} \mathrm{SeO}_{4} 2 \mathrm{H}_{2} \mathrm{O}$. All solutions were diluted in deionized water. The LB broth medium was composed by $5.0 \mathrm{~g} \mathrm{~L}^{-1}$ of meat extract; $10.0 \mathrm{~g} \mathrm{~L}^{-1}$ of tryptone; $10.0 \mathrm{~g} \mathrm{~L}^{-1}$ of $\mathrm{NaCl}$. The $\mathrm{pH}$ was adjusted to 7.0 by adding aliquots of either $\mathrm{HCl}$ or $\mathrm{NaOH}$. The media was sterilized by autoclaving at $121{ }^{\circ} \mathrm{C}$ for $20 \mathrm{~min}$. Flasks were incubated at $30^{\circ} \mathrm{C}$ with orbital shaking $(150 \mathrm{rpm})$ with three replicates. After growth for 5 days in TMM, or $12 \mathrm{~h}$ in LB, an aliquot of $1.0 \mathrm{~mL}$ was taken from the cultures and diluted in saline solution, plated on agar nutritive medium and incubated for $24 \mathrm{~h}$ at $30^{\circ} \mathrm{C}$ in the dark. Colonies were directly counted and expressed as cfu $\mathrm{mL}^{-1}$. In these intervals, the $\mathrm{C} 12 \mathrm{O}$ activity was assayed as described below.

\section{Preparation of cell free extract}

The cells were harvested from LB or TMM by centrifugation $\left(10,000 \mathrm{rpm}\right.$, for $10 \mathrm{~min}$ at $\left.5{ }^{\circ} \mathrm{C}\right)$. The pellet was washed twice with phosphate buffer $(50 \mathrm{mM}, \mathrm{pH} 7.0)$ and re-suspended in $10 \mathrm{~mL}$ of same buffer. Suspensions were sonicated with repeated $40 \mathrm{~s}$ bursts alternated with $1 \mathrm{~min}$ cooling in ice. Cells debris was centrifuged at 12,000 rpm for $15 \mathrm{~min}$. Supernatants were used to enzyme assay and protein estimation.

\section{Enzyme immobilization}

The enzyme was immobilized with calcium alginate matrix technique (Kalogeris et al., 2006). One milliliter of crude extract $(9000 \mathrm{U})$ was suspended in $9 \mathrm{~mL}$ of $2 \%(\mathrm{w} / \mathrm{v})$ sodium alginate prepared in $50 \mathrm{mM}$ Tris- $\mathrm{HCl}$ buffer solu- 
tion ( $\mathrm{pH}$ 8.0). After homogenization of the mixture, the enzyme was dropped into $100 \mathrm{~mL}$ of $0.2 \mathrm{M} \mathrm{CaCl}_{2}$ solution, using a pipette. Upon contact with the solution, the drops were gelled to form defined-sized spheres ( $3 \mathrm{~mm}$ of diameter) which remained in the solution under gentle agitation to complete gel formation. After $1 \mathrm{~h}$ of incubation, the beads were removed, washed twice with sterile distilled water and stored at $4{ }^{\circ} \mathrm{C}$.

\section{Enzyme assay and protein concentration}

Activity of the soluble and immobilized catechol 1,2-dioxygenase enzyme was assayed spectrophotometrically by measurement the increase in absorbance at $\lambda=260 \mathrm{~nm}$, corresponding to the formation of cis, cis-muconic acid. All determinations were made in duplicate for each sample. The reaction mixtures contained $1 \mathrm{~mL}$ of soluble or immobilized enzyme preparations; $1 \mathrm{~mL}$ of $0.8 \mathrm{mM}$ catechol; $0.8 \mathrm{~mL}$ of $50 \mathrm{mM}$ Tris- $\mathrm{HCl}$ buffer solution ( $\mathrm{pH} 8.0$ ) and $0.2 \mathrm{~mL}$ of $0.1 \mathrm{mM} \mathrm{2-mercaptoetanol}$ (Hegman, 1966). After the addition of the enzyme (in both cell free extract and immobilized form), mixtures were incubated at $30^{\circ} \mathrm{C}$ in a water-bath. At certain time intervals, aliquots were used to monitor the reaction progress in spectrophotometer. The protein concentration in supernatant cell free extract was estimated with method described by Bradford (1976), using bovine serum albumin as a standard.

\section{Effect of $\mathrm{pH}$, temperature and ions and maintenance} of enzyme activity

The isolate was inoculated in Erlenmeyer flasks with LB broth containing $250 \mathrm{mg} \mathrm{L}^{-1}$ of anthracene as fine crystals and incubated at $30^{\circ} \mathrm{C}, 150 \mathrm{rpm}$, with two replicates. After growth of 36 hours, the $\mathrm{C} 12 \mathrm{O}$ activity was assayed in the cell free extract and immobilized extract as described above. The optimum $\mathrm{pH}$ was determined by measuring the activity at $30^{\circ} \mathrm{C}$ over the $\mathrm{pH}$ range from 4.0 to 9.0 , using the following buffers: $50 \mathrm{mM}$ acetate $(\mathrm{pH} 4.0-5.5), 50 \mathrm{mM}$ phosphate (pH 6.0-8.0) and $50 \mathrm{mM}$ Tris- $\mathrm{HCl}(\mathrm{pH} 7.0-9.0)$. The optimum temperature was determined by assaying the enzyme activity at various temperatures (from 5 to $50^{\circ} \mathrm{C}$ ) in $50 \mathrm{mM}$ Tris- $\mathrm{HCl}$ buffer solution ( $\mathrm{pH} \mathrm{8.0)}$. The ions tested were $\mathrm{Cu}^{2+}, \mathrm{Mg}^{2+}, \mathrm{Hg}^{2+}, \mathrm{Mn}^{2+}, \mathrm{Fe}^{2+}, \mathrm{K}^{+}$and $\mathrm{NH}_{4}^{+}$at a

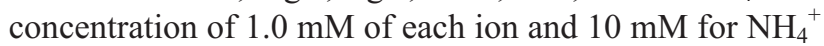
in $50 \mathrm{mM}$ Tris- $\mathrm{HCl}$ buffer solution ( $\mathrm{pH} \mathrm{8.0)}$ ), at temperatures of 25 and $50{ }^{\circ} \mathrm{C}$ in cell free extract and immobilized extract respectively. Ions were not added to control than those in the buffer. The chemicals used were copper sulphate, magnesium chloride, mercury chloride, manganese chloride, iron chloride, potassium acetate and ammonium sulphate. The maintenance of activity of $\mathrm{C} 12 \mathrm{O}$ was determined by measuring the activity in $50 \mathrm{mM}$ Tris- $\mathrm{HCl}$ buffer solution ( $\mathrm{pH} \mathrm{8.0)}$ during $90 \mathrm{~min}$, at temperatures 25 and $50{ }^{\circ} \mathrm{C}$ in the cell free extract and immobilized extract respectively.

\section{Results}

\section{Media and growth profile}

The Mycobacterium growth slowly in the mineral medium and anthracene as only source of carbon and energy (Figure 1A). The growth rate was only $0.0024 \mathrm{~h}^{-1}$ and the maximum enzymatic activity $\left(0.88 \mathrm{mM} \mathrm{mL}^{-1}\right)$ was occurred after 15 days. To reduce the incubation time, the $M y$ cobacterium was cultivated in LB broth with anthracene, which increased the growth rate to $0.0138 \mathrm{~h}^{-1}$ and resulted after $36 \mathrm{~h}$ of incubation in high cells number and high enzymatic activity $\left(1.62 \mathrm{mM} \mathrm{mL}^{-1}\right)$, being two-fold higher to that in the mineral medium (Figure 1B).

\section{Effect of $\mathrm{pH}$}

To both cell free extract and immobilized extract the highest $\mathrm{C} 12 \mathrm{O}$ enzyme activity was at $\mathrm{pH} 8.0$ (Figure 2). In a range between $\mathrm{pH} 4.0$ and 5.5 , the enzyme activity was reduced, although, the immobilized extract showed two-fold higher than cell free extract, showing that the immobilization protected the enzyme against the deleterious effects of the low $\mathrm{pH}$. In a range of $\mathrm{pH}$ from 6.5 to 7.5 , the immobilized extract showed the activity $15 \%$ higher than cell free extract. This protection also was observed at $\mathrm{pH} 8.5$, show-
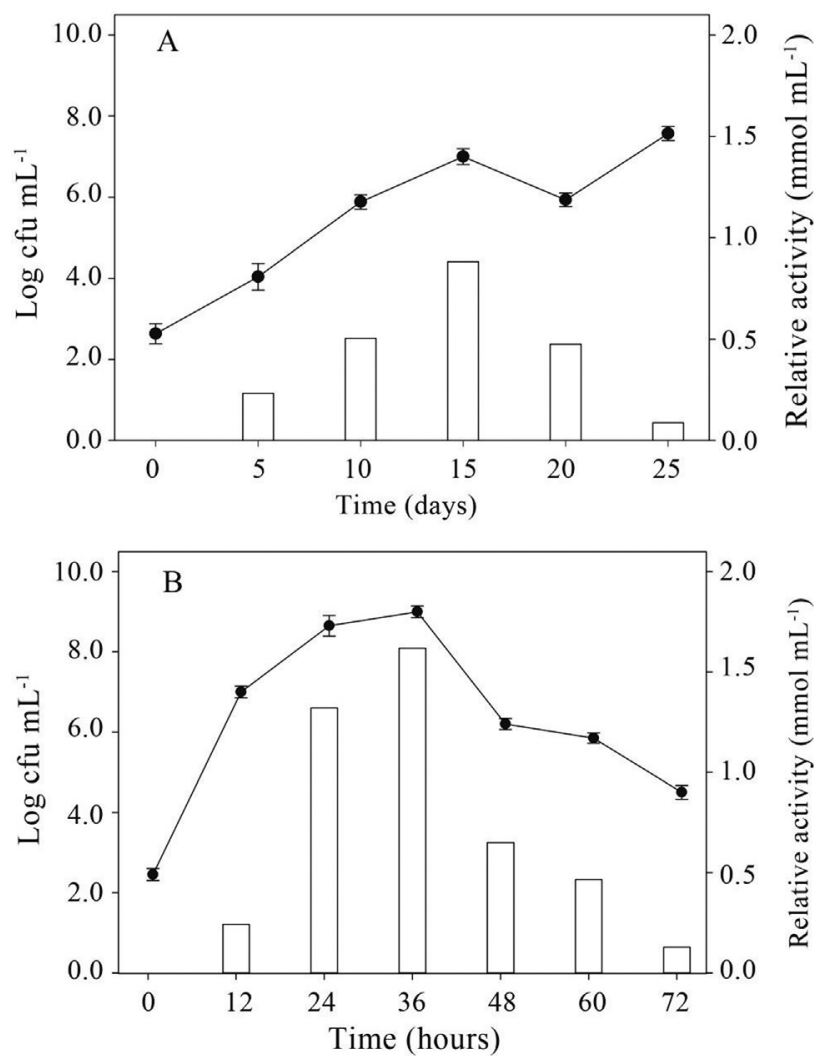

Figure 1 - Growth profile (lines) and enzyme activity of catechol 1,2-dioxygenase (bars) of isolate Mycobacterium fortuitum grown for $150 \mathrm{rpm}$ at $30^{\circ} \mathrm{C}$ in Tanner mineral medium (A) and in Luria-Bertani broth (B), both containing $250 \mathrm{mg} \mathrm{L}^{-1}$ of anthracene (data are mean of three replicates; error bars are standard error). 


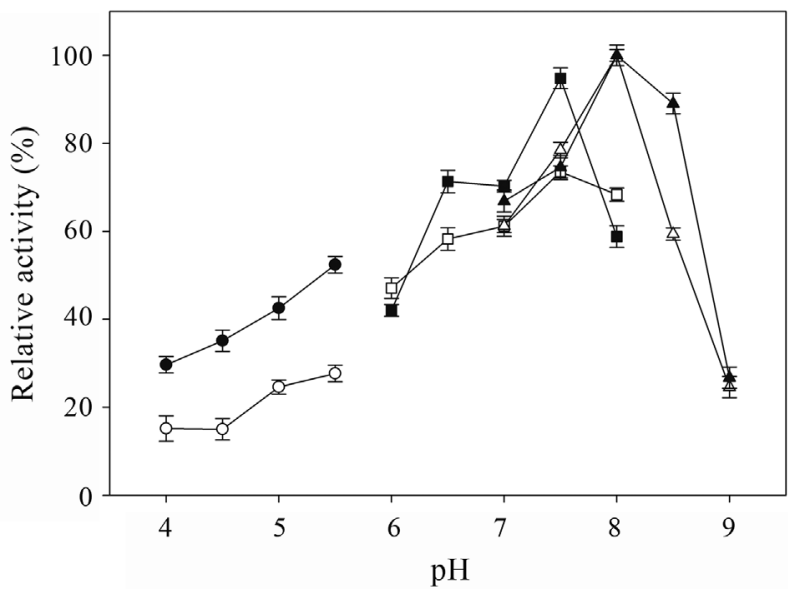

Figure 2 - Effect of $\mathrm{pH}$ in the catechol 1,2-dioxygenase activity present in the cell free extract (white symbols) and immobilized extract (black symbols) of Mycobacterium fortuitum. Buffers: acetate ( $\mathrm{pH} 4.0$ to 5.5 - cycle symbols), phosphate ( $\mathrm{pH} 6.0$ to 8.0 - square symbols), and tris- $\mathrm{HCl}(\mathrm{pH}$ 7.0 to 9.0 - triangle symbols) (data are mean of two replicates; error bars are standard error).

ing that this effect is not just restrict to acid $\mathrm{pH}$ but also in alkaline $\mathrm{pH}$. However, the activity was substantial reduced at $\mathrm{pH} 9.0$ in the cell free extract as much as in the immobilized extract.

\section{Effect of temperature}

The cell free extract showed the $\mathrm{C} 12 \mathrm{O}$ enzyme relative activity of $16 \%$ when incubated at $5{ }^{\circ} \mathrm{C}$ (Figure 3). This activity slightly increased until $20^{\circ} \mathrm{C}$, than strongly increased until the maximum activity at $25^{\circ} \mathrm{C}$. Above $35^{\circ} \mathrm{C}$, it was drastically reduced the activity achieving values near to zero at temperature $45^{\circ} \mathrm{C}$. Thus, the enzyme activity of the cell free extract was kept above $50 \%$ only in a temperature range between 20 and $35^{\circ} \mathrm{C}$. On the other hand, the immobilized extract showed zero enzymatic activity in the

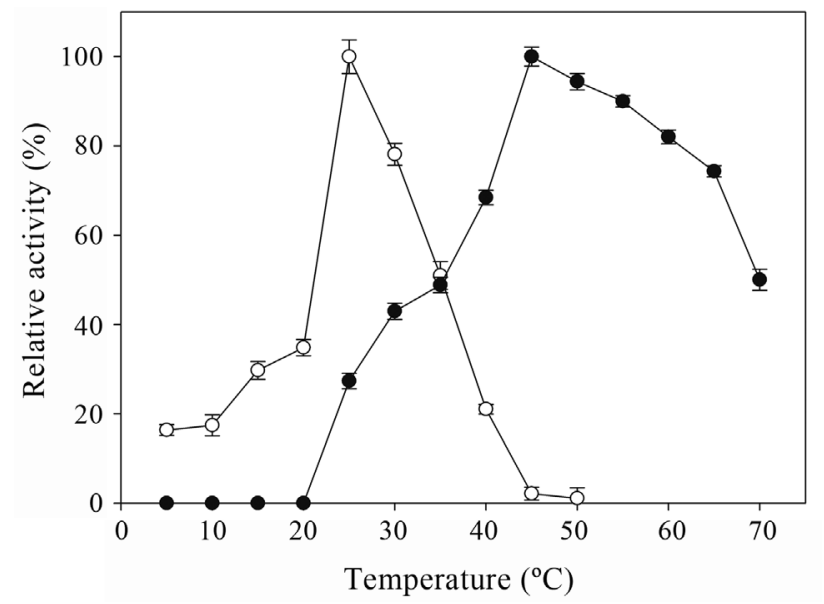

Figure 3 - Temperature effect in activity of the catechol 1,2-dioxygenase enzyme in the cell free extract (o) and immobilized extract $(\bullet)$ of Mycobacterium fortuitum (data are mean of two replicates; error bars represent standard error). temperature range between 5 and $20^{\circ} \mathrm{C}$, than strongly increased until maximum activity at $45^{\circ} \mathrm{C}, 20^{\circ} \mathrm{C}$ higher than the greatest temperature in the cell free extract. The immobilized extract remained with enzyme activity (above 50\%) in a high range of temperature between 35 and $70^{\circ} \mathrm{C}$. However, the extract immobilization promoted a high increase in enzyme activity at temperatures above $35^{\circ} \mathrm{C}$, but reduced the enzyme activity in temperatures under this value.

\section{Maintenance of activity}

The enzyme in the cell free extract showed activity during $70 \mathrm{~min}$ (Figure 4). In the first $20 \mathrm{~min}$ the $\mathrm{C} 12 \mathrm{O}$ enzyme kept high activity, and then it decreased linearly until $70 \mathrm{~min}$. The $\mathrm{C} 12 \mathrm{O}$ enzyme activity in the immobilized extract was detected with more than $90 \mathrm{~min}$, although, it showed a strongly decrease in the enzyme activity in the initial period when compared with cell free extract. Between 20 and $60 \mathrm{~min}$, the activity was near to $50 \%$, than, it decreased until 90 min of incubation. The enzyme immobilization increased the enzymatic activity time, where in the last 50 min of incubation, the enzyme activity of the immobilized extract showed $24 \%$ higher than the cell free extract activity, although, in the first $40 \mathrm{~min}$ free extract showed enzymatic activity $24 \%$ higher than the immobilized extract.

\section{Effect of the ions}

The cell free extract by M. fortuitum showed C12O activity inhibition by ions presence in the following order: $\mathrm{NH}^{4+}>\mathrm{Cu}^{2+}>\mathrm{K}^{+}>\mathrm{Mg}^{2+}$ (Table 1). However, the $\mathrm{Mn}^{2+}$, $\mathrm{Fe}^{3+}$ and $\mathrm{Hg}^{2+}$ stimulated the enzyme activity, showing a relative increasing of more than $50 \%$. In the immobilized extract, the $\mathrm{C} 12 \mathrm{O}$ enzyme was inhibited only by the copper $(11 \%)$ and ammonium (40\%). The potassium did not affect the reaction; however, the magnesium inhibited the enzyme activity in the cell free extract, and in the immobilized ex-

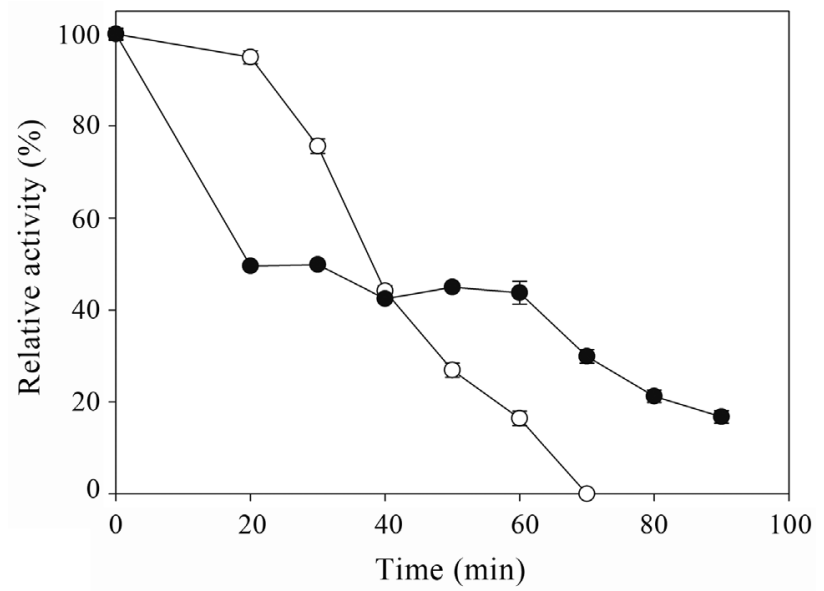

Figure 4 - During time of activity of the catechol 1,2-dioxygenase enzyme in the cell free extract (o) and immobilized extract ( $\bullet$ ) of Mycobacterium fortuitum (data are mean of two replicates; error bars are standard error). 
Table 1 - Effect of ions in relative enzymatic activity of catechol 1,2-dioxygenase present in the cell free extract and immobilized extract of the Mycobacterium fortuitum (the control treatment is the activity in absence of ions).

\begin{tabular}{lccc}
\hline \multirow{2}{*}{ Ion } & $\begin{array}{c}\text { Concentration } \\
(\mathrm{mM})\end{array}$ & \multicolumn{2}{c}{ Relative activity $\%)$} \\
\cline { 3 - 4 } & & Cell free extract & Immobilized extract \\
\hline Control & - & $100 \pm 4.5^{*}$ & $100 \pm 1.3$ \\
$\mathrm{Fe}^{3+}$ & 1.0 & $156 \pm 1.6$ & $206 \pm 0.7$ \\
$\mathrm{Hg}^{2+}$ & 1.0 & $156 \pm 2.1$ & $161 \pm 1.4$ \\
$\mathrm{Mn}^{2+}$ & 1.0 & $151 \pm 4.0$ & $148 \pm 0.4$ \\
$\mathrm{Mg}^{2+}$ & 1.0 & $91 \pm 3.4$ & $138 \pm 0.1$ \\
$\mathrm{~K}^{+}$ & 1.0 & $62 \pm 1.4$ & $102 \pm 0.6$ \\
$\mathrm{Cu}^{2+}$ & 1.0 & $60 \pm 1.1$ & $89 \pm 2.5$ \\
$\mathrm{NH}_{4}^{+}$ & 10.0 & $52 \pm 2.5$ & $60 \pm 1.5$ \\
\hline
\end{tabular}

*Values are means \pm standard error of the mean. (data are average of two replicates \pm standard error).

tract was stimulated by this ion with $38 \%$ more activity. $\mathrm{Fe}^{3+}, \mathrm{Hg}^{2+}$ and $\mathrm{Mn}^{2+}$ stimulated the enzyme activity of the both cell free and immobilized extract with highlighted efficiency, once, the $\mathrm{Fe}^{3+}$ ion showed activity twice higher than others in the immobilized extract.

\section{Discussion}

The low growth of the Mycobacterium isolate and the low $\mathrm{C} 12 \mathrm{O}$ enzyme activity in the Tanner mineral medium is probably due to carbon limitation to the bacteria. The anthracene has very low solubility in water $\left(0.076 \mathrm{mg} \mathrm{L}^{-1}\right)$, moreover, the carbon transferring rate from the solid phase (anthracene crystals) to the liquid phase (mineral medium) is very low (Johnsen et al., 2005; Wich et al., 2001), which it can limit the Mycobacterium growth, and consequently the $\mathrm{C} 12 \mathrm{O}$ enzyme activity. However, the source of soluble carbon used in the medium together with the aromatic compounds seems that it not affected the $\mathrm{C} 12 \mathrm{O}$ enzyme activity. This observation has important biotechnological implications, because it indicates that it is possible to obtain large amounts of cells of Mycobacterium fortuitum and with high activity of $\mathrm{C} 12 \mathrm{O}$ from a non expensive culture medium and in a short period of time, since relatively small amounts of aromatic compound were added to the medium.

In a previews study, it was verified that the microbial consortium with the isolates Mycobacterium fortuitum, $\mathrm{Ba}$ cillus cereus, Microbacterium sp., Gordonia polyisoprenivorans, they have been degraded $48 \%, 67 \%$, and $22 \%$ of the anthracene, phenanthrene, and pyrene in the mineral medium, respectively, after 30 days of incubation in the soil (Jacques et al., 2007). In our study, only the isolate Mycobacterium fortuitum exhibited the pick of the enzyme activity after 15 days of incubation with $0.9 \mathrm{mmol} \mathrm{L}^{-1}$ of anthracene. It shows the potential use of this kind of biotechnology.
The behavior of the $\mathrm{C} 12 \mathrm{O}$ produced by Mycobacterium fortuitum in a $\mathrm{pH}$ range of 4.0 to 9.0 was similar to that showed by Acinotobacter (Briganti et al., 1997) and Rhodococcus (Shunkova et al., 2009), which all isolates showed high activity in the $\mathrm{pH}$ range between 6.0 and 8.0. The $\mathrm{C} 12 \mathrm{O}$ enzyme immobilization with calcium alginate did not modified the optimum $\mathrm{pH}$ of enzyme activity $(\mathrm{pH}$ 8.0 ), result also showed by Kalogeris et al. (2006) which immobilized the $\mathrm{C} 12 \mathrm{O}$ produced by Pseudomonas putida with calcium alginate. However, the enzyme immobilization promoted the increase in the activity in a $\mathrm{pH}$ range between 4.0 and 8.5, showing that the immobilization with the calcium alginate promoted an microenvironment where the enzyme has a higher activity, because it is partially protected from deleterious effect of the $\mathrm{H}^{+}$and $\mathrm{OH}^{-}$concentration (Matto and Husain, 2009; Quiroga et al., 2011).

The enzyme activity might change with different temperatures and some metals soluble in the medium (Andreazza et al., 2011). The variation in the $\mathrm{C} 12 \mathrm{O}$ activity when changed the temperature occurred in this study was similar to that showed by Kalogeris et al. (19), which the difference of the optimal temperature for $\mathrm{C} 12 \mathrm{O}$ activity produced by $P$. putida between the cell free extract and immobilized extract was $15{ }^{\circ} \mathrm{C}$. The contrasting behavior of $\mathrm{C} 12 \mathrm{O}$ activity in different temperature ranges in cell free and immobilized extract indicates that according to the temperature of the wastewater, there are advantages to use cell free or immobilized extract in the bioremediation treatment.

The immobilization can increase molecular stability of the immobilized enzyme, as a result of reduced thermal inactivation (Constantini et al., 2009; Mateo et al., 2000). Gottschalk and Jaenicke (1991) showed that immobilized enzymes have an increase of the enzyme rigidity, which it is commonly reflected by increasing the stability toward denaturation. The $\mathrm{C} 12 \mathrm{O}$ activity showed higher duration in the immobilized extract than the cell free extract. A common mechanism of a multimeric enzyme (such as most catechol dioxygenases) inactivation is the dissociation of enzyme subunits (Kalogeris et al., 2006). Immobilization of biocatalysts by entrapment in calcium alginate gel beads has been reported to improve significantly enzyme stability (Roy and Gupta, 2004). Under these circumstances, stabilization of the quaternary structure of a protein through immobilization could promote enzyme stability and improve its activity (Iyer and Ananthanarayan, 2008).

In many proteins, metal ions interactions play catalytic roles; in others, the metals appear to have a purely structural role. The $\mathrm{Fe}^{3+}$ was the ion with more stimulation in the activity of the $\mathrm{C} 12 \mathrm{O}$ enzyme in the cell free extract and immobilized extract. The $\mathrm{Fe}^{3+}$ has a catalytic function and also a structural function to enzymes that can cleavage catechol intradiol, which the metal ion withdrawal has influence on the secondary structure of $\mathrm{C} 12 \mathrm{O}$, in particular a reduction of $\alpha$-helices content (Di Nardo et al., 2004). In relation to the 
effect of the $\mathrm{Mn}$ in the intradiol-cleaving enzymes, Wang et al. (2006) showed that the activity of the $\mathrm{C} 12 \mathrm{O}$ produced by $P$. aeruginosa was inhibited (only $32 \%$ of the relative activity, with $0.5 \mathrm{mM}$ ) by the presence of this ion in the mix reaction. It was not related that $\mathrm{Mn}^{2+}$ promoted the activity of the $\mathrm{C} 12 \mathrm{O}$, although, many enzymes have this ion in their structure and have their catalytic activity depending of $\mathrm{Mn}^{+2}$ (Crowley, 2000). Other wise, the same author have been find $18 \%$ of increase in the relative activity with $\mathrm{Fe}^{+2}$ ions, and $4 \%$ with $\mathrm{Mg}^{+2}$ (Wang et al., 2006).

$\mathrm{Hg}^{2+}$ was the second ion that promoted the $\mathrm{C} 12 \mathrm{O}$ activity. Some researchers showed that $\mathrm{Hg}^{2+}$ ion decreased the $\mathrm{C} 12 \mathrm{O}$ enzyme activity (Matsumura et al., 2004; Murakami et al., 1998), and in some studies achieved almost $0 \%$ of the relative activity in the concentration of the $0.1 \mathrm{mM}$ of $\mathrm{Hg}^{+2}$ (Murakami et al., 1998). In the current study, this ion showed stimulation; however, the stimulation effect by $\mathrm{Hg}^{2+}$ ions was observed in other enzymes (Anthony, 1997; Karamitsu, 1968). $\mathrm{Cu}^{2+}$ drastically inhibited the $\mathrm{C} 12 \mathrm{O}$ enzyme activity produced by $P$. putida (Wang et al., 2006), Geobacillus sp. (Giedraityte and Kalëdienë, 2009) and Alcaligenes xylosoxidans (Yeom and Yoo, 1999). However, the inhibition was lower than that showed by these authors, mainly by the immobilized enzyme. This behavior was observed not only to $\mathrm{Cu}^{2+}$, but also to all ions that showed inhibitory effect in the $\mathrm{C} 12 \mathrm{O}$ activity $\left(\mathrm{Mg}^{2+}, \mathrm{K}^{+}\right.$, $\mathrm{Cu}^{2+}$ and $\mathrm{NH}^{4+}$ ). Krajewska (2004) showed that the ions diffusion through the solid barrier constituted by the substrate is low, reducing the inhibitors interference in the immobilized enzyme.

The catechol dioxygenases has a fundamental pathway in the carbon biochemical cycle and a high biotechnological potential in the treatment of liquid wastes contaminated with aromatics compounds. Nevertheless, there are few studies with catechol 1,2-dioxygenase from gram-positives and actinobacteria. In this study, it was demonstrated that the immobilization of the $\mathrm{C} 12 \mathrm{O}$ enzyme from Mycobacterium fortuitum was significantly increased in the catalytic activity in the low and high $\mathrm{pH}$ conditions, high temperatures and in presence of the activity inhibitors. Extreme conditions such as above cited can be in the contaminated wastes, showing that the immobilization with a cheap substrate, not toxic and simple manipulation such as calcium alginate can contribute to turn this enzyme an efficient biotechnological alternative to treatment of liquid wastes contaminated with aromatic compounds.

\section{Acknowledgments}

Thanks to CNPq and CAPES by the financial support and scholarships.

\section{References}

Andreazza R, Okeke Benedict C, Pieniz P, Brandelli A, Lambais MR, Camargo FAO (2011) Bioreduction of $\mathrm{Cu}(\mathrm{II})$ by cell- free copper reductase from a copper resistant Pseudomonas sp. NA. Biol Trace Elem Res 143:1182-1192.

Andreoni V, Gianfreda L (2007) Bioremediation and monitoring of aromatic-polluted habitats. App Microb Biotechnol 76:287-308.

Anthony R (1997) Ashton and Gabriele M. Siegel. Stimulation of spinach (Spinacia oleracea) chloroplast fructose-1,6-bisphosphatase by mercuric ions. FEBS Lett 408:30-32.

Bradford MM (1976) A rapid e sensitive method for the quantitation of microgram quantities of protein utilizing the principle of protein-dye binding. Anal Biochem 72:248-254.

Briganti F, Pessione E, Giunta C, Scozzafava A (1997) Purification, biochemical properties and substrate specificity of a catechol 1,2-dioxygenase from a phenol degrading Acinetobacter radioresistens. FEBS Lett 416:61-64.

Costantini AS, Gorini G, Consonni D, Miligi L, Giovannetti L, Quinn M (2009) Exposure to benzene and risk of breast cancer among shoe factory workers in Italy. Tumori 95:8-12.

Crowley JD, Traynor DA, Weatherburn DC (2000) Enzymes and proteins containing manganese: An overview. Met Ions Biol Syst 37:209-278.

Di Nardo G, Tilli S, Pessione E, Cavaletto M, Giunta C, Briganti F (2004) Structural roles of the active site iron(III) ions in catechol 1,2-dioxygenases and differential secondary structure changes in isoenzymes A and B from Acinetobacter radioresistens S13. Arch Biochem Bioph 431:79-87.

Durán N, Esposito E (2000) Potencial applicantions of oxidative enzyme and phenoloxidase-like compounds in wastewater and soil treatment: A review. App Catalysis B 28:83-99.

Fernandez-Lafuente R, Guisan, J.M.; Ali, S.; Cowan, D. (2000) Immobilization of functionally unstable catechol-2,3-dioxygenase greatly improves operational stability. Enzyme Microb Tech 26:568-573.

Giedraityte G, Kalëdienë L (2009) Catechol 1,2-dioxygenase from $\alpha$-naphthol degrading thermophilic Geobacillus sp. strain: Purification and properties. Cent Eur J Biol 4:68-73.

Gottschalk N, Jaenicke R (1991) Authenticity and Reconstitution of Immobilized Enzymes: Characterization and Denaturation/Renaturation of Glucoamylase II. Biotechnol Appl Bioc 14:324-335.

Hegman GD (1966) Synthesis of the enzymes of the mandelate pathway by Pseudomonas putida. J Bacteriol. 91:11401154.

Iyer PV, Ananthanarayan L (2008) Enzyme stability and stabilization - Aqueous and non-aqueous environment. Process Biochem 43:1019-1032.

Jacques RJS, Okeke BC, Bento FM, Peralba MCR, Camargo FAO (2007) Characterization of a polycyclic aromatic hydrocarbon-degrading microbial consortium from a petrochemical sludge landfarming site. Bioremed J 11:1-11.

Jacques RJS, Okeke BC, Bento FM, Teixeira AS, Peralba MC, Camargo FAO (2008) Microbial consortium bioaugmentation of a polycyclic aromatic hydrocarbons contaminated soil. Bioresource Technol 99:2637-2643.

Johnsen AR, Wick LY, Harms H (2005) Principles of microbial PAH-degradation in soil. Environ Pollut 133:71-84.

Macleod CT, Daugulis AJ (2005) Interfacial effects in a twophase partitioning bioreactor: Gedradation ps polycyclic aromatic hydrocarbons (PAHs) by a hydrophobic Mycobacterium. Process Biochem 40:1799-1805. 
Kalogeris E, Sanakis Y, Mamma D, Christakopoulos P, Kekos D, Stamatis H (2006) Properties of catechol 1,2-dioxygenase from Pseudomonas putida immobilized in calcium alginate hydrogels. Enzyme Microb Tech 39:1113-1121.

Karamitsu HK (1968) Mercury(II) stimulation of malate dehydrogenase activity. The J Biol Chem 243:1016-1021.

Kiyohara H, Nagao K, Yana K (1982) Rapid screen for bacteria degrading water-insoluble, solid hydrocarbons on agar plates. Appl Environ Microbiol 43:454-457.

Krajewska B (2004) Application of chitin and chitosan based materials for enzyme immobilizations: A review. Enzyme Microb Tech 35:126-139.

Mateo C, Palomo JM, Fernandez-Lorente G, Guisan JM, Fernandez-Lafuente R (2007) Improvement of enzyme activity, stability and selectivity via immobilization techniques. Enzyme Microb Tech 40:1451-1463.

Mateo C, Abian O, Fernandez-Lafuente R, Guisan JM (2000) Increase in conformational stability of enzymes immobilized on epoxy-activated supports by favoring additional multipoint covalent attachment. Enzyme Microb Tech 26:509515 .

Matsumura E, Ooi S, Murakami S, Takenaka S, Aoki K (2004) Constitutive synthesis, purification, and characterization of catechol 1,2-dioxygenase from the aniline-assimilating bacterium Rhodococcus sp. AN-22. J Biosci Bioeng 98:71-76.

Matto M, Husain Q (2009) Calcium alginate-starch hybrid support for both surface immobilization and entrapment of bitter gourd (Momordica charantia) peroxidase. J Mol Catal. B-Enzym 57:164-170.
Murakami S, Wang CL, Naito A, Shinke R, Aoki K (1998) PuriWcation and characterization of four catechol 1,2-dioxygenase isozymes from the benzamide-assimilating bacterium Arthrobacter species BA-5-17. Microbiol Res 153:163-171.

Quiroga E, Illane S CO, Ochoa NA. Barberis, S. (2011). Performance improvement of araujiain, a cystein phytoprotease, by immobilization within calcium alginate beads. Process Biochem. 46:1029-1034.

Roy I, Gupta NM (2004) Hydrolysis of starch by a mixture of glucoamylase and pullulanase entrapped individually in calcium alginate beads. Enzyme Microb Technol 34:26-32.

Shumkova ES, Solyanikova IP, Plotnikova EG, Golovleva LA (2009) Phenol degradation by Rhodococcus opacus Strain 1G. Appl Biochem Microbiol 45:43-49.

Tsai SC, Li YK (2007) Purification and characterization of a catochel 1,2-dioxygenase from a phenol degrading Candida albicans TL3. Arch Microbiol 187:199-206.

Wang CL, You SL, Wang SL (2006) Purification and characterization of a novel catechol 1,2-dioxygenase from Pseudomonas aeruginosa with benzoic acid as a carbon source. Process Biochem 41:1594-1601.

Wick LY, Colangelo T, Harms H (2001) Kinetics of mass transfer-limited bacterial grownth on solid PAHs. Environ Sci Tech 35:354-361.

Whiteley CG, Lee JD (2006) Enzyme technology and biological remediation. Enzyme Microb Tech 38:291-316.

Yeom SH, Yoo YJ (1999) Removal of benzene in a hybrid bioreactor. Process Biochem 34:281-88.

All the content of the journal, except where otherwise noted, is licensed under a Creative Commons License CC BY-NC. 